\title{
EXPERIMENTAL STUDY OF THE IMPACT OF THE VEGETABLE COLD STORE FLOOR LOCATION ON HEAT EXCHANGE WITH THE SOIL
}

\author{
SOKOLOWSKI, P. ${ }^{*}$ - NAWALANY, G. \\ Department of Rural Building, Faculty of Environmental Engineering, University of Agriculture \\ in Krakow, al. Mickiewicza 24/28, 30-059 Krakow, Poland \\ (e-mail: kbw@urk.edu.pl; phone: +48-12-662-4009) \\ ${ }^{*}$ Corresponding author \\ e-mail:p.sokolowski@urk.edu.pl \\ (Received 18 ${ }^{\text {th }}$ Feb 2019; accepted 10 ${ }^{\text {th }}$ Apr 2019)
}

\begin{abstract}
The paper analyses the impact of location of the vegetable cold store floor in relation to the ground level on heat exchange with the soil. The scope includes the analysis of indoor and outdoor temperature and soil temperature under the cold store and its surrounding, specification and adaptation of the cold store heat exchange model with soil, calculations for chosen variants in non-stationary conditions and a comparative analysis of cold store heat exchange with soil and soil temperature in chosen solutions. The paper used the results of field studies conducted in a cold store located in southern Poland. The said building was used to store carrots from 1 October to 30 June. Three calculation variants were used in order to determine in detail the impact of the chosen factors on heat exchange between the cold store and soil. The calculations were made based on the elementary balances method in WUFI ${ }^{\circledR}$ plus software. The calculation model was validated based on the results of field studies of indoor and outdoor temperature and soil temperature in 5 measurement lines at the depth of $0.05,0.50,1.00$ and $1.50 \mathrm{~m}$. The obtained validation results showed a very high correlation of measurement data and calculated data and an absence of significant differences. The calculation results for 3 variants showed statistically significant $(p<0.05)$ differences in both soil temperature and heat exchange with the soil.
\end{abstract}

Keywords: cooling chamber, energy management, energy efficiency, microclimate, ground temperature

\section{Introduction}

In order to preserve an adequate commercial, nutritional and biological quality, the picked fruit should be stored at a precisely specified temperature, humidity and with an appropriate gas composition and lighting in the store (Sun et al., 2004; Zhihang et al., 2006). Appropriate storage is intended mainly to reduce the intensity of microbiological, chemical, physical and biological processes causing unfavourable quality changes of the product (Łapczyńska-Kordon and Krzysztofik, 2008; Mazzeo et al., 2015). Such processes include breathing, transpiration, change of chemical composition, ripening and ageing, and damage caused by various pathogens. Changes in the fruit chemical composition take place at a various rate depending on many factors such as cultivation, fruit species and variety and, most of all, storage conditions (Wu et al., 2012; Phillips et al., 2016). Active cooling and controlled storage atmosphere is used to reduce the risk of deterioration of quantitative and qualitative factors (Liu et al., 2010; Ambaw et al., 2013; East et al., 2013). Other methods of preservation include application of edible coats, potentially not hazardous to humans, the main purpose of which is inter alia to prevent the fruit discoloration and to destroy harmful bacteria. The main benefit of such treatment is a significant extension of the shelf life of stored products (Soliva-Fortuny and Martin-Belloso, 2003; Albanese et al., 2007). 
The heat exchange with soil is an issue that is well known and described in the literature. The studies in this area were conducted by inter alia Radon et al. (2014), Nawalany et al. (2014, 2017), Aresti et al. (2018), Janssen (2002) and Deru (2001). Due to a large accumulation potential of soil, partially earth-sheltered buildings have a reduced demand for heating and cooling energy in comparison to non-earth-sheltered buildings, assuming the functional and spatial solutions in such buildings are similar (Dronkelaar et al., 2014).

The paper aimed at determining the impact of cold store floor location relative to the ground level on heat exchange between the floor and the soil.

\section{Materials and methods}

The field studies were conducted in a vegetable cold store in southern Poland. The said cold store has a set of rooms, with the manipulation area located at the head of the row of two cold rooms. The sorting and packing areas are located in the northern part of the building, and the cold rooms in the south-eastern and south-western part. The total building area is $232 \mathrm{~m}^{2}$, including $58 \mathrm{~m}^{2}$ of sorting and packing areas, $96 \mathrm{~m}^{2}$ of righthand cold room and $78 \mathrm{~m}^{2}$ of left-hand cold room. The building has a steel frame structure on a $30-\mathrm{cm}$ wide concrete foundation located $1.0 \mathrm{~m}$ below the ground level. Important for the heat exchange with the soil is the fact that the foundation is not thermally insulated. The chamber floors are made of $10-\mathrm{cm}$ thick cement screed and feature a 4-cm thick thermal insulation of hard EPS. An organoleptic soil examination showed that the cold store surrounding includes a 40-cm thick humus layer, with a $1.5-\mathrm{m}$ thick layer of silty clay below it. The outside walls and ceiling of the chambers are made of sandwich panels, comprising steel sheets galvanized and painted on both sides, and a 15-cm thick EPS core. Polyurethane foam was used at the joints of panels to eliminate thermal bridges.

The storage cycle in the examined facility lasted from 15 October to 30 June, with a technological interruption from 1 July to 30 September. The optimum temperature was kept by a $20 \mathrm{~kW}$ refrigerating unit. The cold rooms' dimensions were adapted to multiples of box pallets in which carrots were kept. The distance between the box pallets and walls and between the box pallet rows were $10 \mathrm{~cm}$ to $30 \mathrm{~cm}$ and $5 \mathrm{~cm}$ to $10 \mathrm{~cm}$, respectively.

The field studies were conducted between 1 May 2009 to 30 June 2011, and the period from 1 May 2010 and 30 April 2011 was used for this paper. The studies included continuous measurements of indoor and outdoor air temperature and floor temperature at 1-hour intervals. The temperature was measured by twenty-two APATOR TOP 168 sensors based on a PT100 platinum resistor $\left(0.1^{\circ} \mathrm{C}\right.$ measurement resolution, $0.1^{\circ} \mathrm{C}$ measurement error). The sensors were connected to an HP 34970A recorder. The measurement results were used to validate the calculation model that was used in this paper. Figure 1 shows the building layout and location of the measurement points.

Three calculation variants were applied to study the impact of cold store floor location relative to the ground level on the indoor microclimate and soil temperature under the cold store and in its surrounding: variant 1 - floor on the ground level, variant 2 - floor elevated $+0.75 \mathrm{~m}$ above the ground level, variant 3 - floor sunk $-0.75 \mathrm{~m}$ below the ground level. The simulation was conducted in WUFI ${ }^{\circledR}$ plus software which allows for calculating in a non-stationary approach using the method of elementary balances. 
Prior to the calculation analysis, the software was validated based on actual measuring data. The starting point for the model validation was to build a discrete geometrical model divided into balance-differential elements. The model included measuring points corresponding to their actual location in the field-studied facility (Fig. 2).

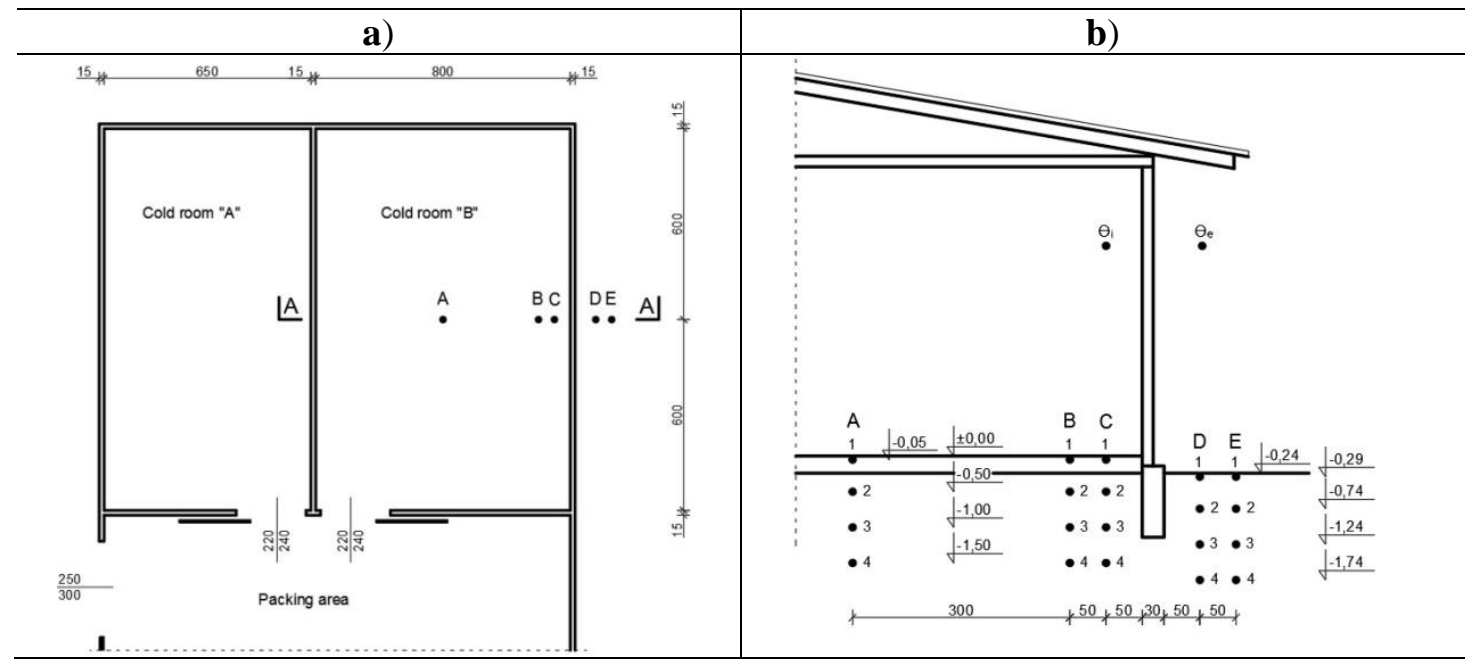

Figure 1. Location of measurement points in the cold store: (a) plan; (b) section $A-A: A, B, C$, $D, E$ - measuring lines, $A 1$ - A4, B1 - B4, C1 - C4, D1 - D4, E1 - E4 - soil temperature measurement points, $\Theta i, \Theta e$ - air temperature measurement points

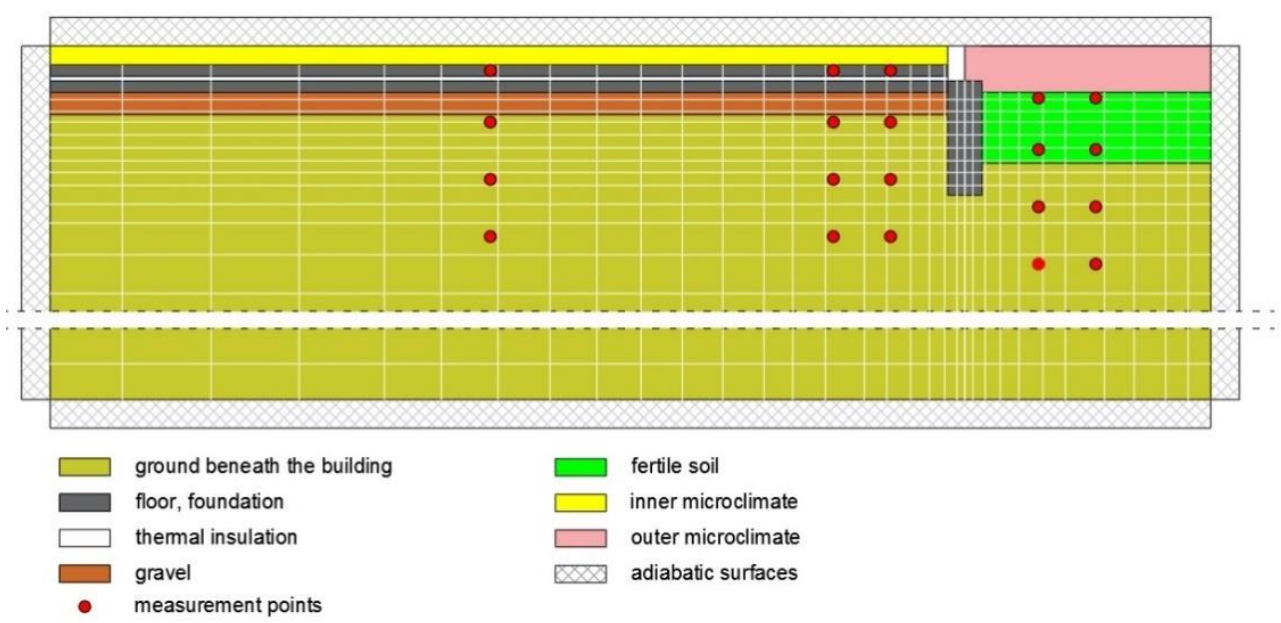

Figure 2. Section of the modelled facility with division network and layout of soil temperature calculation points (model from WUFI®plus software)

The physical parameters of the construction materials and soil used in the calculation model for validation are presented in Table 1. The minimum indoor air temperature used in calculations was $\Theta_{\mathrm{i}, \min }=0^{\circ} \mathrm{C}$, maximum indoor air temperature $\Theta_{\mathrm{i}, \max }=4^{\circ} \mathrm{C}$, minimum indoor air relative humidity $\mathrm{Rh}_{\mathrm{i}, \mathrm{min}}=80 \%$, and maximum indoor air relative humidity $\mathrm{Rh}_{\mathrm{i}, \max }=99 \%$. The natural air change was assumed at $0.3 \mathrm{~h}^{-1}$ and infiltration at $0.2 \mathrm{~h}^{-1}$. The variant calculation analysis was based on climatic data for a typical 
meteorological year (TRY) for Krakow, Poland, available in the WUFI ${ }^{\circledR}$ plus software database. Correlation analysis was performed for results obtained from all the measuring points, based on the Spearman's Rank Test (the data distribution was not normal). The data distribution normality was tested previously using the Shapiro-Wilk Test.

Table 1. Physical parameters of the soil and construction materials used in the calculations

\begin{tabular}{c|c|c|c}
\hline \multirow{2}{*}{ clay } & Specification & Unit & Value \\
\hline \multirow{3}{*}{ humus } & $\begin{array}{c}\text { bulk density } \\
\text { heat capacity } \\
\text { thermal conductivity }\end{array}$ & $\mathrm{kg} \cdot \mathrm{m}-3$ & 1600 \\
& bulk density & $\mathrm{W} \cdot \mathrm{m}-1 \cdot \mathrm{K}-1$ & 1000 \\
& heat capacity & $\mathrm{kg} \cdot \mathrm{m}-3$ & 1.80 \\
\hline \multirow{3}{*}{ styrofoam } & thermal conductivity & $\mathrm{J} \cdot \mathrm{kg}-1 \cdot \mathrm{K}-1$ & 1800 \\
& bulk density & $\mathrm{W} \cdot \mathrm{m}-1 \cdot \mathrm{K}-1$ & 1260 \\
& heat capacity & $\mathrm{kg} \cdot \mathrm{m}-3$ & 20 \\
\hline \multirow{3}{*}{ concrete } & thermal conductivity & $\mathrm{W} \cdot \mathrm{m}-1 \cdot \mathrm{K}-1$ & 1500 \\
& bulk density 1 & 0.04 \\
\hline \multirow{3}{*}{ gravel } & heat capacity & $\mathrm{kg} \cdot \mathrm{m}-3$ & 2300 \\
& thermal conductivity & $\mathrm{W} \cdot \mathrm{mg}-1 \cdot \mathrm{K}-1$ & 1000 \\
& bulk density & $\mathrm{kg} \cdot \mathrm{m}-3$ & 2.30 \\
\hline & heat capacity & $\mathrm{J} \cdot \mathrm{kg}-1 \cdot \mathrm{K}-1$ & 1800 \\
& thermal conductivity & $\mathrm{W} \cdot \mathrm{m}-1 \cdot \mathrm{K}-1$ & 840 \\
& & & 0.90 \\
\hline
\end{tabular}

\section{Results}

\section{Results of experimental studies}

The indoor air temperature during the storage period (15 October - 30 June) was kept between $0.0^{\circ} \mathrm{C}$ and $4.0^{\circ} \mathrm{C}$. During the technological interruption from the beginning of July to the end of September the indoor microclimate in the cold store changed passively depending on the outdoor microclimate; this caused the indoor temperature to increase to $15.3^{\circ} \mathrm{C}$ in August. The maximum outdoor air temperature in that period was $22.3^{\circ} \mathrm{C}$. The indoor temperature fell abruptly in the last week of September after the cooling system had been activated to ensure the optimum temperature from the first day of the storage period - that is 1 October. From 1 October to 6 December the indoor air temperature was kept again at $4.0^{\circ} \mathrm{C}$, with small, short-term drops. The drops were caused by a decrease of the outdoor air temperature and were in the $0.2-0.8^{\circ} \mathrm{C}$ range. In winter the average indoor air temperature in the cold store was in the $1.0-1.6^{\circ} \mathrm{C}$ range, and in the remaining months it was near $4.0^{\circ} \mathrm{C}$ (Fig. 3).

The floor temperature analysis in point $\mathrm{A} 1$ showed $4.2^{\circ} \mathrm{C}$ on the last day of the storage period. On the first day of the next storage cycle, the floor temperature was $11.6^{\circ} \mathrm{C}$ and decreased gradually. It was that in the analysed calculation variant determined the time necessary to reduce the floor temperature to the value from the end of the storage period is 18 days.

In points $\mathrm{C} 1, \mathrm{~B} 1$ and $\mathrm{A} 1$ located in the soil under the cold store, the annual soil temperature amplitude was in the $13.9-14.3^{\circ} \mathrm{C}$ range. A larger impact of the soil on the stabilisation of thermal conditions is visible at the depth of $1.5 \mathrm{~m}$. At the depth of $0.50 \mathrm{~m}$, the annual temperature fluctuations were reduced almost twofold compared to the depth of $0.05 \mathrm{~m}$. The impact of the cold store on the soil temperature decreases with depth. In points located in the facility surrounding, the annual soil temperature 
amplitude was from $14.5^{\circ} \mathrm{C}$ (point D2) to $15.1^{\circ} \mathrm{C}$ (point $\mathrm{E} 2$ ), and in points under the cold store it was from $7.5^{\circ} \mathrm{C}(\mathrm{A} 2), 6.5^{\circ} \mathrm{C}(\mathrm{B} 2)$ and $6.6^{\circ} \mathrm{C}$ in $\mathrm{C} 2$ (Fig. 4).

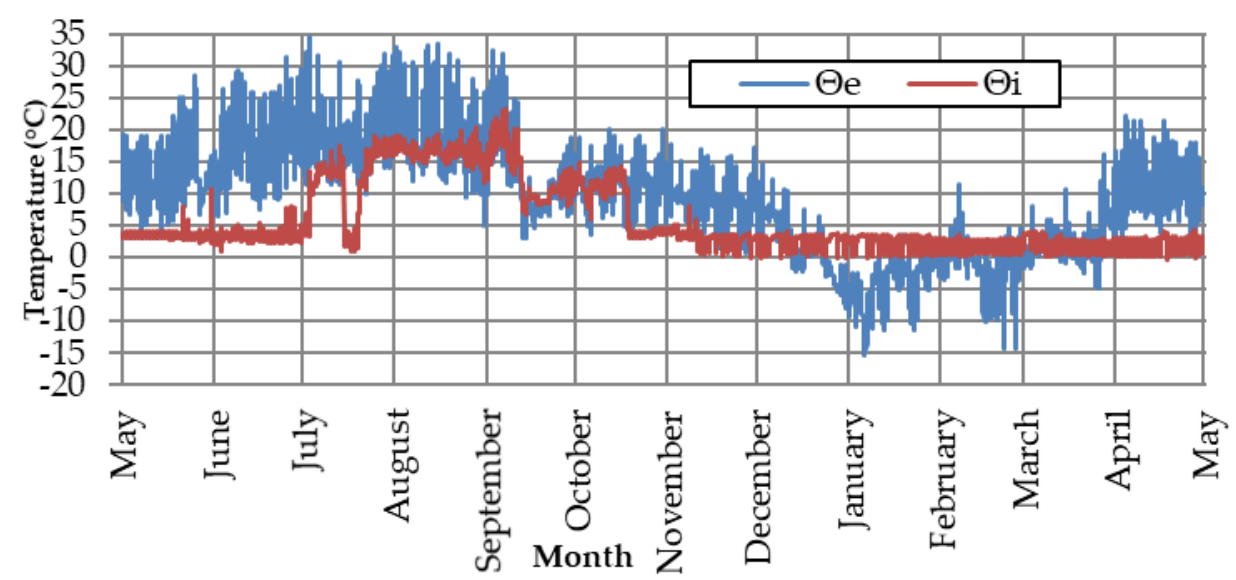

Figure 3. Outdoor $(\Theta e)$ and indoor $(\Theta i)$ air temperature

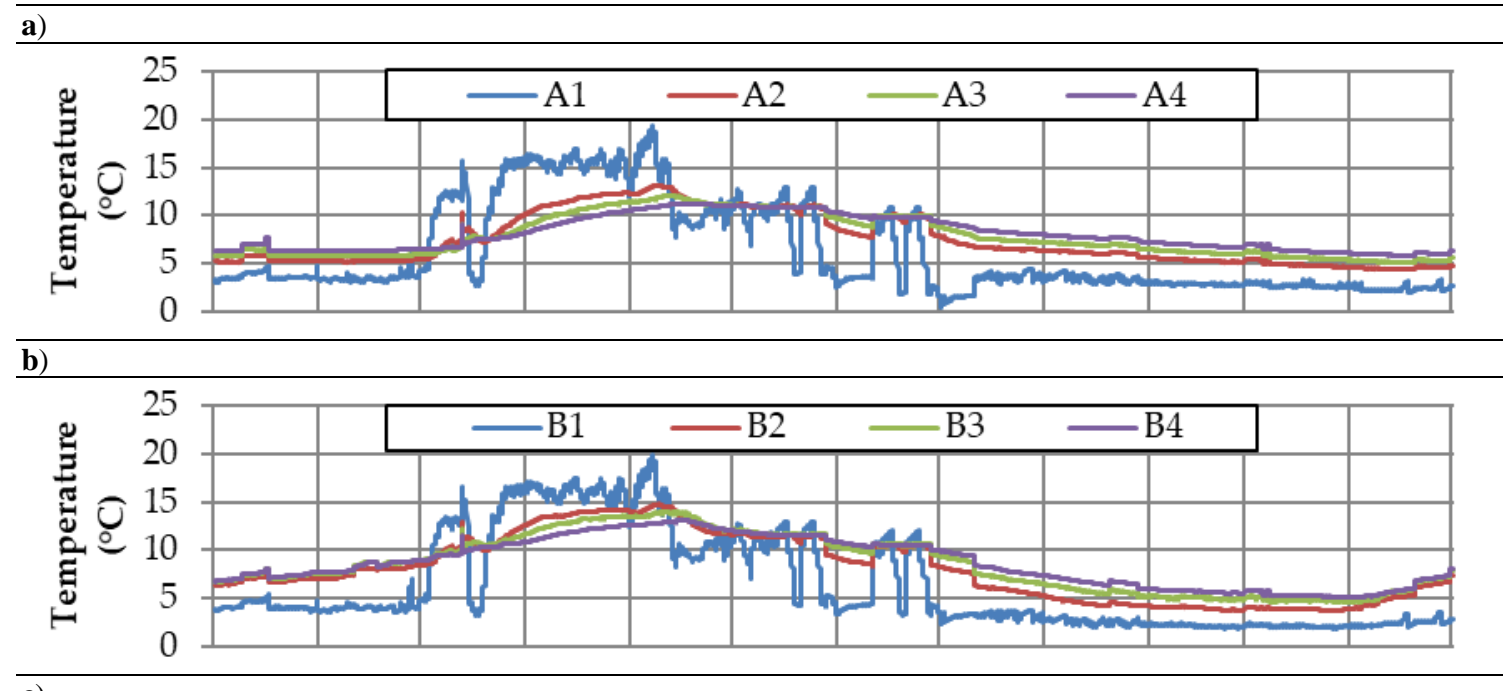

c)

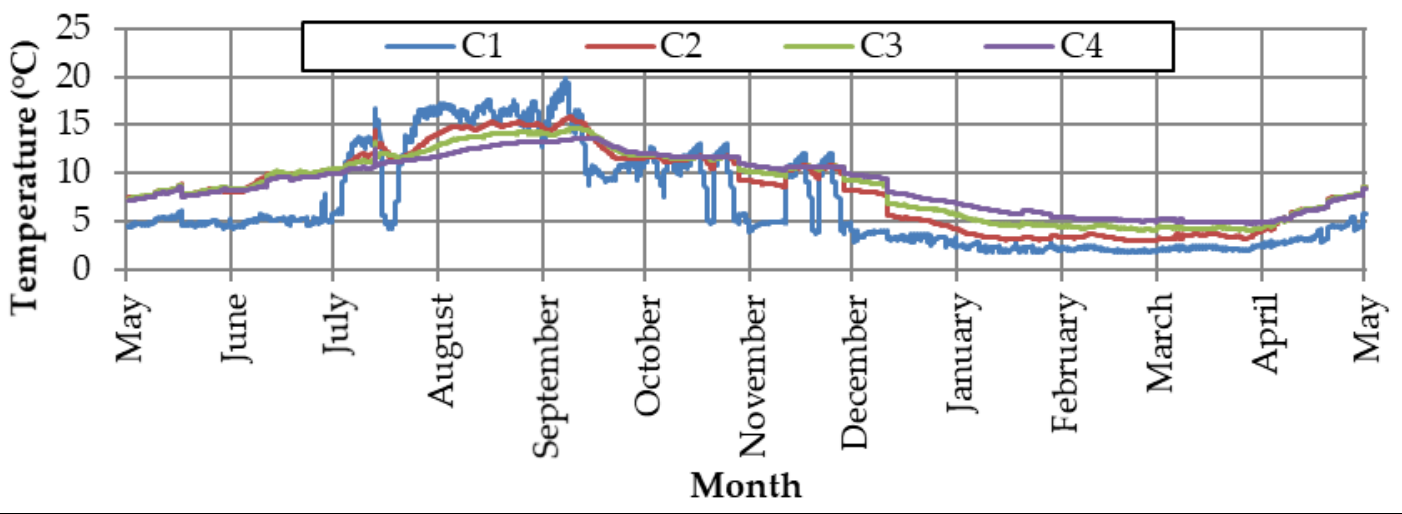

Figure 4. Measured soil temperatures in lines $A, B$ and $C:$ : (a) temperature points $A 1(0.05 m)$, $A 2(0.50 \mathrm{~m}), A 3(1.00 \mathrm{~m}) \mathrm{A} 4(1.50 \mathrm{~m}) ;(\mathrm{b})$ points $B 1(0.05 \mathrm{~m}), B 2(0.50 \mathrm{~m}), B 3(1.00 \mathrm{~m}), B 4$ $(1.50 \mathrm{~m}) ;(\mathrm{c})$ points $C 1(0.05 \mathrm{~m}), C 2(0.50 \mathrm{~m}), C 3(1.00 \mathrm{~m})$ and $C 4(1.50 \mathrm{~m})$ 
The soil temperature in the cold store surrounding depended on the indoor and outdoor air temperature. The annual soil temperature amplitude in point $\mathrm{E} 1$ was $29.4^{\circ} \mathrm{C}$, and at the depth of $1.5 \mathrm{~m}$ in the same measuring line (E4) it was $9.2^{\circ} \mathrm{C}$. The calculation results showed the highest soil temperature in the measuring point $\mathrm{E} 1$ in June $\left(18.8^{\circ} \mathrm{C}\right)$, and the lowest soil temperature $\left(-10.6^{\circ} \mathrm{C}\right)$ was recorded in January in the same measuring point (Fig. 5).

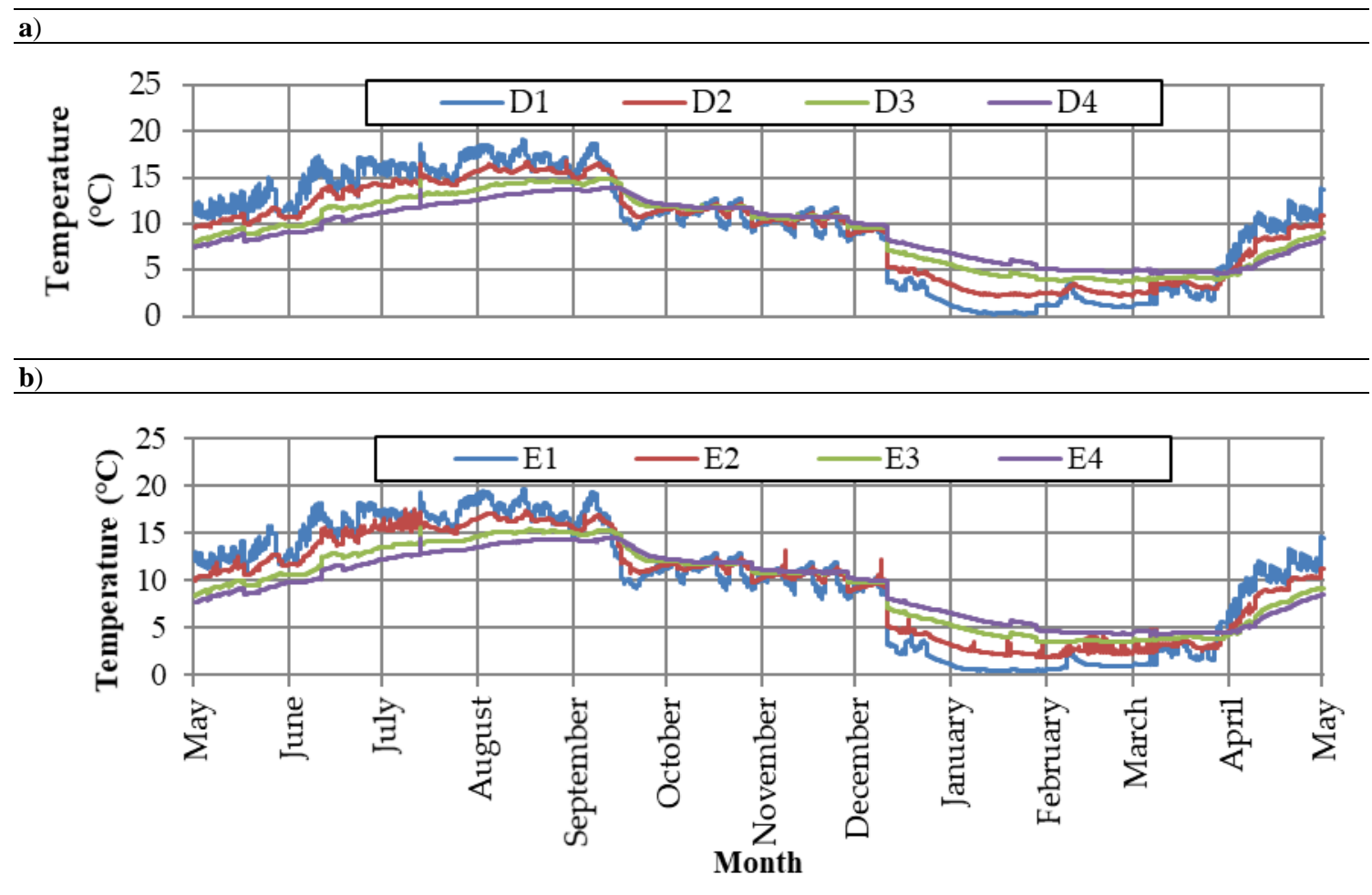

Figure 5. Measured soil temperatures in lines $D$ and $E$ : (a) temperature points D1 (0.05m), D2 $(0.50 \mathrm{~m}), \mathrm{D} 3(1.00 \mathrm{~m}) \mathrm{D} 4(1.50 \mathrm{~m})$; $(\mathrm{b})$ points E1 $(0.05 \mathrm{~m})$, E2 $(0.50 \mathrm{~m})$, E3 $(1.00 \mathrm{~m}), \mathrm{E} 4$ $(1.50 \mathrm{~m})$

\section{Results of generalising calculations}

The calculation model was validated based on measured temperature inside and outside the cold store. In relation to the soil temperature, the measured temperature was a boundary condition of the third kind. The initial soil temperature was assumed at $8.8^{\circ} \mathrm{C}$, which corresponds to the average annual outdoor air temperature for Krakow (TRY).

The highest correlation coefficient $(0.95$ - 0.99) was determined for measuring points E2, E3, E4, D2, D3, D4, C2, C3, C4, B2, B3, B4, A2, A3 and A4. Consequently, the conformity of calculation and measurement data at the depth of $0.50 \mathrm{~m}, 1.00 \mathrm{~m}$ and $1.50 \mathrm{~m}$ can be considered full. In the case of points E1 and D1, located $0.05 \mathrm{~m}$ below the ground level, and A1, B1 and C1 located under the floor, the correlation coefficient was $0.85-0.88$, so the conformity of measurement and calculation data should be considered very high (Fig. 6 and Fig. 7).

It should be emphasised that in winter the actual soil temperature at the depth of $0.10 \mathrm{~m}$ differed from the calculated values by $11.2^{\circ} \mathrm{C}$ in line $\mathrm{E}$ and $11.0^{\circ} \mathrm{C}$ in line $\mathrm{D}$. The reason was the impossibility to account for the snow cover. The differences occurred, however, 
only for a short time and were not significant for the entire period of study. The statistical significance of differences was tested using the Kruskal-Wallis $(\mathrm{p}<0.05)$ test.
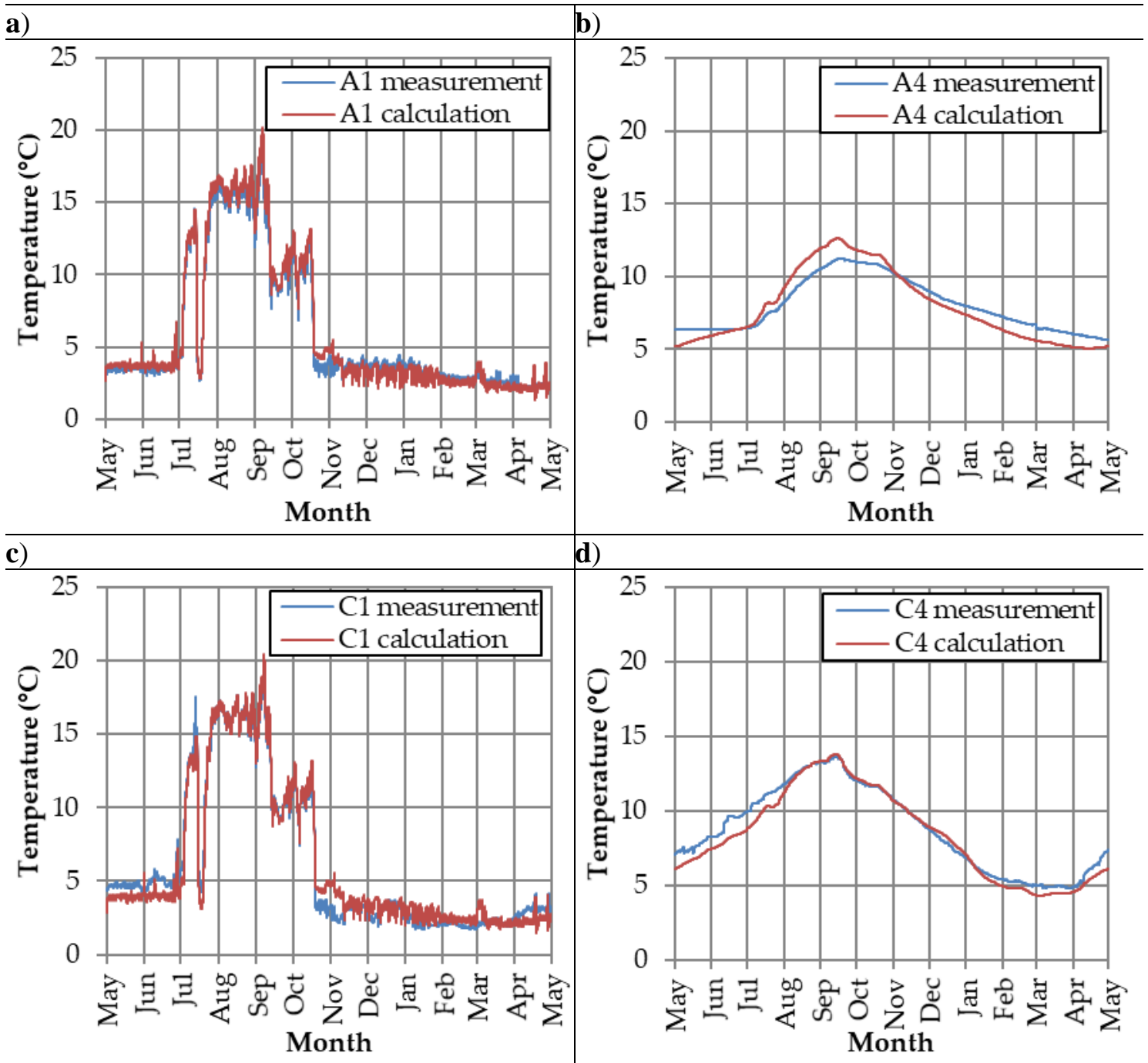

Figure 6. Calculated and actual soil temperature: (a) A1; (b) A4; (c) C1; (d) C4

The analysis of heat exchange intensity between the indoor air and the soil for the cold store with the floor at the ground level (variant 1) showed that the soil share in the total cold store energy balance was $16.6 \%$. The highest energy gains from the soil were discovered in October $(478.5 \mathrm{kWh})$. As a result of technological interruption in the summer, there was an intensive heat flow to the soil in July $(588.1 \mathrm{kWh})$. The location of the cold store floor $+0.75 \mathrm{~m}$ above the ground level (variant 2) reduced the soil share in the energy management to $8.2 \%$ relative to variant 1 . The energy demand for cooling was $4920.5 \mathrm{kWh}$, and for heating $682.7 \mathrm{kWh}$. The analysis of variant with the floor $-0.75 \mathrm{~m}$ under the ground level indicated that such variant significantly increases the soil share in the cold store energy balance relative to variant 1 . During one year the soil share in the cold store energy balance for variant 3 was $32.8 \%$. Similar to the two previously discussed variants, the highest heat gains were in October $(891.5 \mathrm{kWh})$. The analysis of the balance of heat exchange with soil indicated high energy gains of $2054.6 \mathrm{kWh}$ (Fig. 8). 


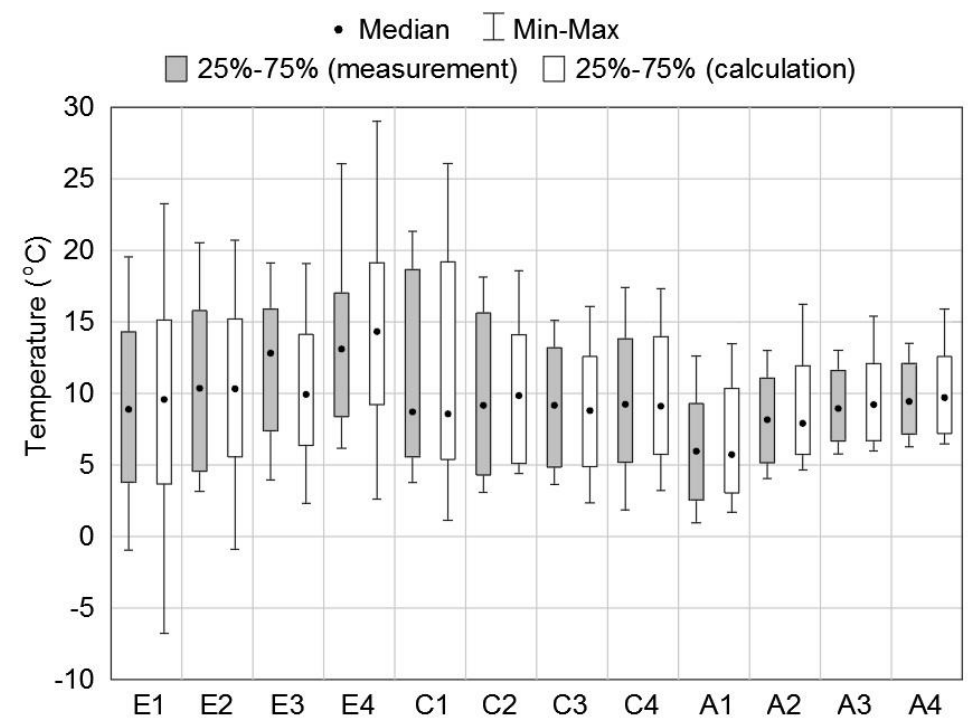

Figure 7. Statistical agreement of the measured and calculated data, E1-E4;C1-C4; A1$A 4-$ floor and ground temperature measurement points
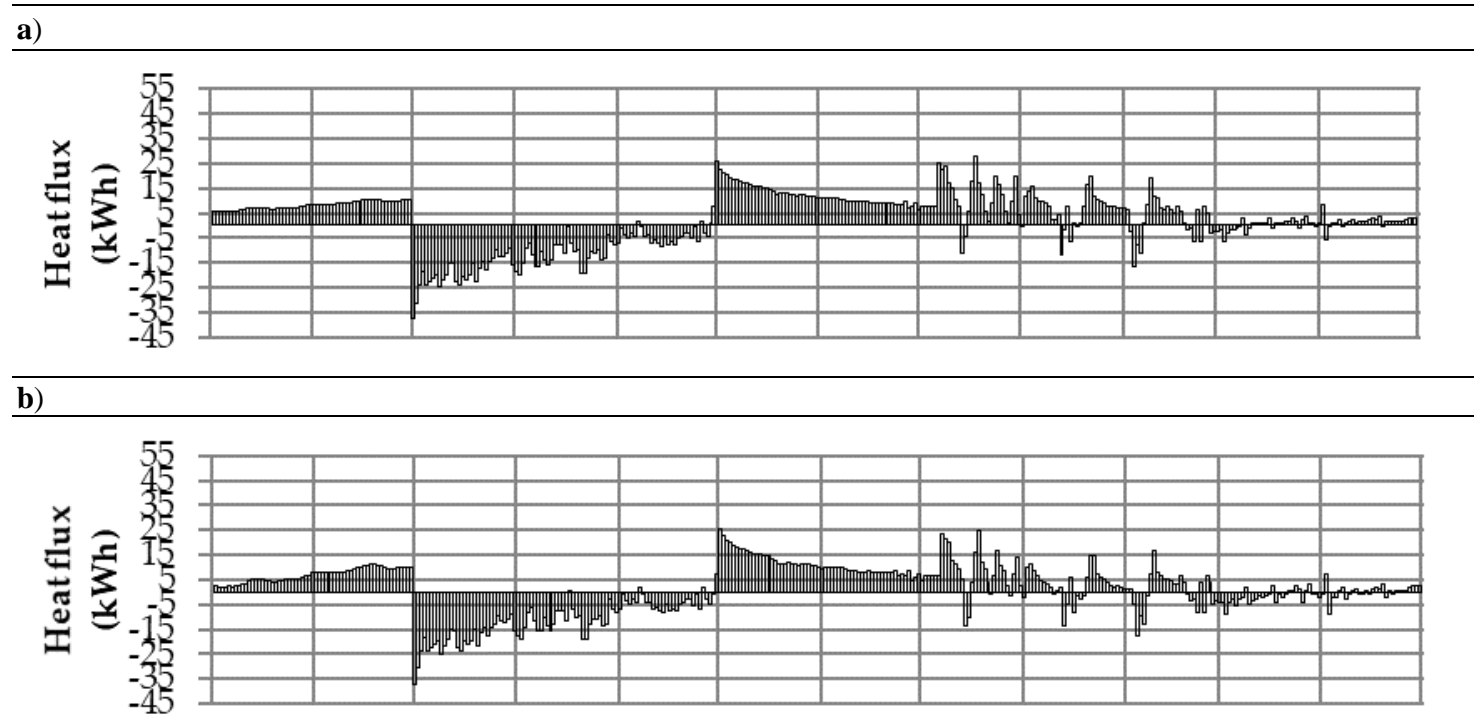

c)

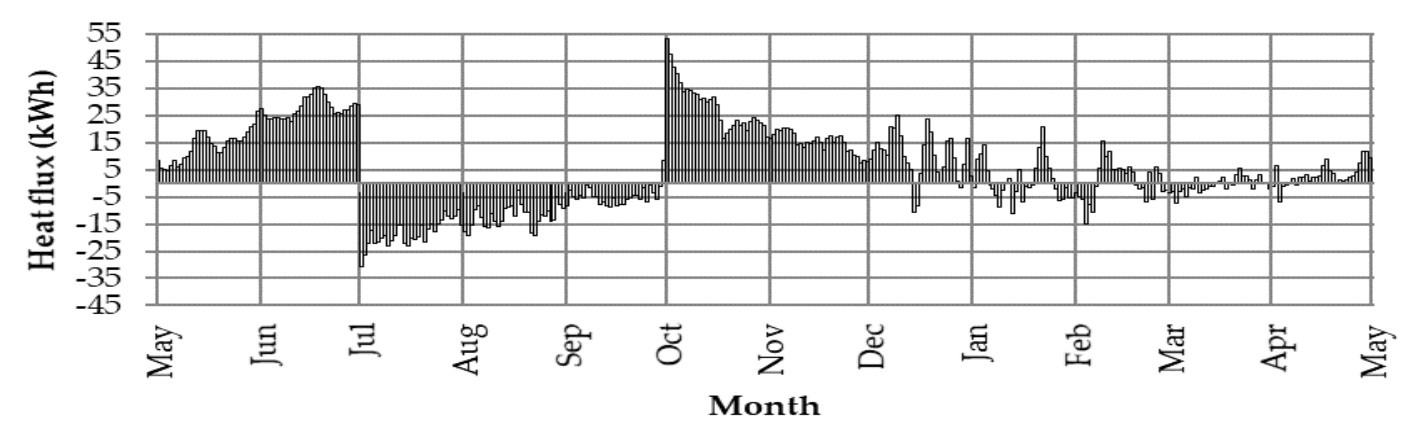

Figure 8. Heat exchange between the cold store and soil: (a) variant 1; (b) variant 2; (c) variant 3 
The highest dynamics of heat exchange with the soil was determined in variant 3 , with a 3-month cooling period from 1 October to 30 June and a 3-month technological interruption from 1 July to 30 September. The annual amplitude of the heat stream flowing through the soil in that period was $4849.4 \mathrm{kWh}$. The least soil share in the total cold store energy balance was found in variant 2 with the floor elevated +0.75 above the ground level (Table 2). The swap of the floor level relative to the ground level affects the decrease of the soil temperature under the cold store even by $4.0^{\circ} \mathrm{C}$. Similar to the soil temperature, the data deviated from the normal distribution also in case of the cold store-soil exchange. The analysis of the significance of differences between the individual variants indicated that all the examined solutions significantly affect the heat exchange between the cold store and soil.

Table 2. Calculation results of the heat exchange between the cold store and soil and the cold store energy demand for heating and cooling, annual balance for all variants

\begin{tabular}{|c|c|c|c|}
\hline & Variant 1 & Variant 2 & Variant 3 \\
\hline Heat gains from the ground $\left(\mathrm{kWh} \cdot \mathrm{rok}^{-1}\right)$ & 2259.1 & 1876.1 & 3452.0 \\
\hline Heat losses to the ground $\left(\mathrm{kWh} \cdot \mathrm{rok}^{-1}\right)$ & -1319.7 & -1417.7 & -1397.4 \\
\hline $\begin{array}{c}\text { Participation of the ground in cold store energy balance throughout } \\
\text { the year }(\%)\end{array}$ & 16.6 & 8.2 & 32.8 \\
\hline Energy demand and for cooling $\left(\mathrm{kWh} \cdot \mathrm{rok}^{-1}\right)$ & 5141.4 & 4920.5 & 5745.5 \\
\hline
\end{tabular}

The results show that the cold store floor elevated $+0.75 \mathrm{~m}$ above the ground level decreases the cooling energy demand by $220.9 \mathrm{kWh}$ per year compared to the variant with the floor at the ground level. The floor located below the ground level seems to be the least favourable option as it significantly increases the cooling energy demand. It should be noted that such a relationship occurs as a result of a unique storage technology. There is a 9-month storage period in the examined cold store, and the technological interruption takes place in the summer.

\section{Discussion}

The obtained generalising results of the simulation can be accepted as reliable and universal for all buildings of this type. Numerical analysis is one of the most accurate and frequently used methods in science (Janssen et al., 2004; Radoń et al., 2014; Nawalany et al., 2017; Dong, 2017; Bambara and Athienitis, 2018). However, the authors have not encountered such analysis for a vegetable cold store. Compared to other agricultural buildings, for example a greenhouses, a cold store has a significantly higher share of soil in the total energy balance of the building. In greenhouses, the soil share in the total energy balance is about 5\% (Nawalany et al., 2014). The results presented in this paper indicate that in a cold store such a value is $16.6 \%$ in the case of the floor on the ground level. The studies (Bambara and Athienitis, 2018; HyungKweon et al., 2018) indicate the need to verify the impact of the cold store thermal insulation at various floor location variants on the intensity of heat exchange with the soil and the soil share in the total energy balance of the building. An adequate building insulation can lead to even a 5-fold decrease of the soil share in energy gains and losses of the building (Nawalany et al., 2017; Dong, 2017). 


\section{Conclusions}

The studies show that the cold store floor location has a significant impact on the heat exchange with the soil. When a cold store is partially earth-sheltered (floor $0.75 \mathrm{~m}$ below the ground level), the heat flow from soil increases even by $16.2 \%$ compared to the variant with the floor at the ground level. A floor elevated above the ground level $(+0.75 \mathrm{~m})$ decreases the heat flow from the soil by $8.4 \%$ compared to the variant with the floor at the ground level. The variants with the floor above and below the ground level significantly affect the cold store energy balance. The share of the foundation and floor in a partially earth-sheltered cold store is $32.8 \%$, and $8.2 \%$ in an elevated cold store $(+0.75 \mathrm{~m})$. Significant differences can also be observed in the cooling energy demand. The most favourable variant is the one with the elevated floor in which the cooling energy demand is $4920.5 \mathrm{kWh}$ /year. The least favourable variant is the one with the floor $-0.75 \mathrm{~m}$ below the ground level as it increases the cooling energy demand to $5745.5 \mathrm{kWh} /$ year.

\section{REFERENCES}

[1] Albanese, D., Cinquanta, I., Di Matteo, M. (2007): Effects of an innovative dipping treatment on the cold storage of minimally processed Annurca apples. - Food Chemistry 105: 1054-1060.

[2] Ambaw, A., Delele, M. A., Defraeye, T., Ho, Q. T., Opara, L. U., Nicolai, B. M., Verboven, P. (2013): The use of CFD to characterize and design post-harvest storage facilities: Past, prezent and future. - Computers and Electronics in Agriculture 93: 184194.

[3] Aresti, L., Christodoulides, P., Florides, G. (2018): A review of the design aspects of ground heat exchangers. - Renewable and Sustainable Energy Reviews 92: 757-773.

[4] Bambara, J., Athienitis, A. K. (2018): Energy and Economic Analysis for greenhouse Ground Insulation Design. - Energies 11(11): 3218. doi:10.3390/en11113218.

[5] Deru, M. (2001): Ground-Coupled Heat and Moisture Transfer from Buildings. - Ph.D. Dissertation, Colorado State Univeristy, Fort Collins, CO.

[6] Dong, C. (2017): Heat Loss via Concrete Slab Floors in Australian Houses. - Procedia Engineering 205: 108-115.

[7] van Dronkelaar, C., Costola, D., Mangkuto, R. A., Hensen, J. L. M. (2014): Heating and cooling energy demand in underground buildings: potential for saving in various climates and functions. - Energy and Buildings 71: 129-136.

[8] East, A. R., Smale, N. J., Trujillo, F. J. (2013): Potential for energy cost savings by utilising alternative temperature control strategies for controlled atmosphere stored apples. - International Journal of Refrigeration 36: 1109-1117.

[9] Hyung-Kweon, K., Geum-Choon, K., Jong-Pil, M., Tae-Seok, L., Sung-Sik, O. (2018): Estimation of Thermal Performance and Heat Loss in Plastic Greenhouses with and without Thermal Curtains. - Energies 11(3): 578. https://doi.org/10.3390/en11030578.

[10] Janssen, H. (2002): The influence of soil moisture transfer on building heat loss via the ground. - Ph.D. Dissertation, Departement Burgerlijke Bouwkunde. Katholieke Universiteit Leuven.

[11] Janssen, H., Cormeliet, J., Hens, H. (2004): The influence of soil moisture transfer on building heat loss via the ground. - Building and Environment 39: 825-836.

[12] Łapczyńska-Kordon, B., Krzysztofik, B. (2008): Wpływ sposobów i czasu przechowywania na wybrane właściwości fizyczne jabłek. - Inżynieria Rolnicza 2(100): 179-185. 
[13] Liu, Y., Langer, V., Hogh-Jensen, H., Egelyng, H. (2010): Life Cycle Assessment of fossil energy use and greenhouse gas emissions in Chinese pear production. - Journal of Cleaner Production 18: 1423-1430.

[14] Mazzeo, T., Paciulli, M., Chiavaro, E., Visconti, A., Pellegrini, N. (2015): Impact of the industrial freezing process on selected vegetables - Part II. Colour and bioactive compounds. - Food Research International 75: 89-97.

[15] Nawalany, G., Bieda, W., Radoń, J., Herbut, P. (2014). Experimental study on development of thermal conditions in ground beneath a greenhouses. - Energy and Buildings 69: 103-111.

[16] Nawalany, G., Radon, J., Bieda, W., Sokolowski, P. (2017): Influence of selected factors on heat exchange with the ground in a greenhouse. - Transactions of the ASABE 60(2): 479-487.

[17] Phillips, K. M., Council-Troche, A., McGinty, R. C., Rasor, A. S., Tarrago-Trani, M. T. (2016): Stability of vitamin $\mathrm{C}$ in fruit and vegetable homogenates stored at different temperatures. - Journal of Food Composition and Analysis 45: 147-162.

[18] Radoń, J., Bieda, W., Lendelova, J., Pogran, S. (2014): Computational model of heat exchange between dairy cow and bedding. - Computers and Electronics in Agriculture 107: 29-37.

[19] Soliva-Fortuny, R., Martin-Belloso, O. (2003): New advances in extending the shelf life of fresh-cut fruits: a review. - Trends in Food Science \& Technology 14: 341-353.

[20] Sun, D.-W., Wang, L. (2004): Experimental investigation of performance of vacuum cooling for commercial large cooked meat joints. - Journal of Food Engineering 61(4): $527-532$.

[21] Wu, Z. S., Zhang, M., Wang, S. (2012): Effects of high pressure argon treatments on the quality of fresh-cut apples at cold storage. - Food Control 23: 120-127.

[22] Zhang, Z., Sun, D.-W. (2006): Effect of cooling methods on the cooling efficiencies and qualities of cooked broccoli and carrot slices. - Journal of Food Engineering 77(2): 320326. 